\title{
Revisiting the Effectiveness of Blackboard Learning Management System in Teaching English in the Era of COVID-19
}

\author{
Mohammad H. Al-khresheh ${ }^{1}$ \\ ${ }^{1}$ Department of English Language, Faculty of Science and Arts, Northern Border University, Saudi Arabia \\ Correspondence: Mohammad H. Al-khresheh, Department of English Language, Faculty of Science and Arts, \\ Northern Border University, Saudi Arabia.
}

Received: July 21, 2021

doi:10.5430/wjel.v12n1p1
Accepted: October 6, $2021 \quad$ Online Published: October 8, 2021

URL: https://doi.org/10.5430/wjel.v12n1p1

\begin{abstract}
The study carries out a detailed review of the overall impact of deploying the Blackboard online platform in the EFL teaching-learning process. In pursuing this aim, this study has followed the narrative literature approach, using analytical and comparative techniques as primary research methods. Numerous studies have been analysed thoroughly to conclude whether these technology-oriented tools directly affect the EFL teaching-learning process. The study also provides a definitive opinion regarding the usefulness of blackboard technology. The analysis of literature pointed out that EFL classes were positively influenced when Blackboard technology was utilised. Blackboard technology's advantages in EFL were found to outnumber their disadvantages. However, technical challenges remain in integrating this technology successfully into modern classrooms. It should also be noted that while such technology-based teaching tools are a step in the right direction, they should not be considered as a perfect replacement for time-tested teacher-student classroom interactions that happen organically in classrooms. Additional preparation is also required from both teachers and students to make a meaningful contribution to such technology-oriented classes. Particularly, teachers need much training, encouragement, and support to move towards further advanced and collaborating pedagogies online.
\end{abstract}

Keywords: blackboard, covid-19, e-learning, English, LMS, teaching process

\section{Introduction}

The COVID-19 pandemic caused a phenomenal shift in modern learning systems, as schools were forced to adopt online learning methods en masse. However, online learning systems have been around for many years now. The pandemic has forced schools to adopt the new system suddenly. Since the early 2000s, online learning and teaching platforms have been steadily rising (Al-Khresheh, 2021; Mahyoob, 2020). In response to ever-changing online learning and teaching methodologies, many tools have also been developed to make online learning technologies more efficient and useful to both teachers and students. One of the biggest challenges with online learning platforms is distinguishing effectively between the online educational platforms available today to make the right choice. The need of the hour is to create an efficient learning platform capable of enhancing the existing course content delivery methods to encourage effective learning and teaching (Al-Mashaqbeh, 2009; Baker \& Watson, 2014; Butler \& Sellbom 2002; Carrillo \& Flores, 2020).

With the rise of new e-learning tools and systems, educational institutions from all over the globe are racing to implement them as part of their academic curriculum (Al-Senaidi et al., 2009). English as a foreign language (EFL) programmes are also increasingly provided online to provide better assistance and personalised interactions to learners. Learners are also encouraged to engage in individualised and incentivised learning strategies (Abdalla, 2005; Aldosari \& Mekheimer, 2013; Beard, 2017; Bower et al., 2017; Boulton et al., 2018; Demirkol-Orak \& İnözü, 2021). EFL courses combine virtual learning environments to achieve better results. Online EFL courses are being offered via modern e-learning systems that promote effective learning and teaching practices (Al-Qahtani, 2019; Alsowayegh et al., 2019; Bukhari \& Basaffar, 2019).

In today's world, there are multiple Learning Management Systems (LMS) that cater to the needs of students and teachers. Educational institutions select their systems based on internal policy requirements after considering the academic requirements of their students and teachers. LMS technology has widely permeated the entire globe, with its adoption rates seeing accelerated growth due to the COVID-19 pandemic (Al-Fadhli, 2008; Al-Qahtani, 2019). Published by Sciedu Press 
Some of the most widely used LMS platforms include Blackboard, Moodle ${ }^{\circledR}$, WebCT, and LAMS, with Blackboard being the platform of choice for most higher education institutions (Mohsen \& Shafeeq, 2014). Blackboard technology happens to be a popular Internet tool used by educational institutions to facilitate the submission of important files like documents, student reports, assignments, and other announcements from teachers to their students. Blackboard technology also enables other activities in real-time, such as live chat rooms that students and teachers can use to transfer documents, questions, and resources between each other. In Higher Education, Blackboard is well-thought-out at the front of contemporary technological advances. Several leading educational institutes have adopted this technology as an online LMS for all students. With the hurried growth of the use of such technology-oriented classes, understanding their impact on users becomes essential (Butler \& Sellbomm 2002; Larkin \& Belson, 2005; Servonsky \& Bertha, 2005).

\subsection{The Study's Research Question}

With the unexpected rise in the adoption of such tech-oriented learning systems, accelerated by the COVID-19 pandemic, it has become necessary to analyse and review the overall impact of using such systems in teaching EFL courses. To find out how effective utilizing such digital systems in the teaching-learning process, this study is set to answer the following research question:

$>$ How effective is utilizing the Blackboard technology learning system in the EFL teaching-learning process?

\section{Research Methods}

A narrative literature review is the main approach followed in this study. Such an approach helps in reviewing and evaluating pertinent literature. The approach also helps in ascertaining trends and patterns in the literature. Therefore, inconsistencies in a body of knowledge can be significantly identified (Snyder, 2019).

\subsection{The Study's Objective}

This study explores the impact of the Blackboard technology learning system on the EFL teaching-learning process by providing a definitive opinion regarding the effectiveness of blackboard technology. This technology has been selected in this study because it is currently a prominent education technology assisting over 150 million students and teachers in every region of the world (Alkhaldi \& Abualkishik, 2019; Alokluk, 2018).

\subsection{Data Collection}

To answer the main research question of this study, a group of only peer-reviewed studies about Blackboard use in general and English language teaching, in particular, were carefully selected. The selection of these studies was based on three main criteria: 1) the relevance of these studies to the main focus of this study, 2) the novelty and recency of these studies, and 3) the indexing of journals where these studies are published.

\subsection{Data Analysis}

To analyse data gathered for the main purpose of this study, two important methods, namely the analytical and comparative methods, were employed. These two methods are considered the most powerful in reviewing a particular topic in a specific field to demonstrate the weaknesses and strengths (Gay \& Airasian, 2005).

The analytical method was used as a primary research method after thoroughly considering various domestic, foreign, and current works of literature. This method is chosen because it first allows for data identification and synthesis to generate much-needed answers to pressing research queries (Babbie, 2005; Siddaway et al., 2019). Secondly, this method takes a rigorous, thorough approach to various forms of literature, deploying predetermined procedures for minimising prejudice. This also benefits increasing the overall reliability of the study's findings (Braver et al., 2014). Owing to this method, it is much easier to locate, analyse, and systematicly synthesize data from a diverse group of academic, scientific, and research studies. Moreover, this method helps identify the strengths and weaknesses of the previous studies' findings. As a result, new conclusions can be drawn and integrated accurately, based on the patterns and relationships shared between earlier studies in the same field (Gay \& Airasian, 2005).

A thorough analysis cannot be made without comparing it to other similar systems. Therefore, the comparative method is another crucial analysis method used in this study that has been built into the fundamental framework of this theme. Lack of proper comparison diminishes the conclusions of any scientific research or opinion (Garside, 2014). Comparing previous studies regarding objectives, methods, and findings can help draw better conclusions (Azarian, 2011; Babbie, 2005; Glasziou, 2001).

Structure-wise, a systematic review of the LMS has been done to determine their efficiency at EFL teaching. A detailed analysis of the utilization and implementation of modern Blackboard technology has also been made to 
reflect the primary differences distinguishing this technology from the competition. The perspectives recorded by the users (students and teachers) regarding technology integration measures in class have been reviewed and discussed.

\section{Discussion}

The way teachers teach and learners learn is subject to the potentiality of new technologies to change. The assortment and growth of online resources and traditional teaching practices can be highly affected by these technologies (Coates, 2007). Hrastinski (2009) asserts, "If we want to enhance online learning, we need to enhance online learning participation" (p. 81). Therefore, he has advocated a theory of online learning which encourages the idea that online participation presupposes online learning in a more influential mode. Accordingly, when there is collaboration and involvement among learners, online education becomes abundant.

Recently, the teaching-learning process has rapidly assumed a new and drastic dimension, with multiple advanced technologies replacing traditional tools (Julian et al., 2019). Today, the existence of flexible, cost-effective, and efficient technologies enhances knowledge acquisition and transfer (Tschand et al., 2021). Currently, digital (e-learning) tools consistently eliminate numerous challenges hindering the transfer of ideas and intellectual collaborations across borders, such as long distances and the cost of transportation. E-learning platforms or Learning Management Systems (LMS) are internet-based learning systems rapidly adopted by educational institutions worldwide to completely revamp the learning experience for students and teachers (Aldosari \& Mekheimer, 2013; Eldridge, 2014). In reality, E-learning technologies ensure seamless teaching and learning while virtually enhancing communication and exchanging learning resources (Poon, 2013. For instance, LMS enables teachers to supervise materials and assignments directly while coordinating assessments and evaluating students' progress (Lin et al., 2017). They also help teachers communicate effectively and provide course materials directly to students (Al-Fadhli, 2008; Ayres, 2002; Bacher-Hicks et al., 2020). Likewise, students can also access materials shared by teachers, submit assignments, and communicate with unknown instructors regarding their courses (Butler \& Sellbom, 2002; Coates et al., 2005). However, it is imperative to note that LMS cannot be expected to completely replace the traditional/conventional classroom atmosphere within a short period (Mahyoob, 2020). However, the principal aim of applying LMS is to supplement the traditional system by offering course content in an easily accessible format outside traditional education centres and classrooms (Landry et al., 2006; Poon, 2013). The introduction of new digital technologies has completely changed the learning and teaching paradigm, which has remained unchanged since the late 1990s despite consistent yet insufficient progress. Moreover, unlike several past world socio-economic and political problems, the COVID-19 pandemic forced educational institutions to accelerate their LMS systems by adopting sustainable virtual blackboard technologies for teaching and learning, especially in the English Language (Mahyoob, 2020; Xie et al., 2020).

\subsection{General Insights on Learning Management Systems}

LMS technologies existed for a couple of years but became popular recently due to the COVID-19 pandemic (Sousa \& Rocha, 2019). Recent research indicates that the 2020 pandemic resulting in global economic, political, and educational shutdown primarily inspired educational institutions to adopt LMS in the teaching-learning process since face-to-face interactions were limited. Today, several universities, colleges, and high schools have successfully migrated to virtual teaching and learning with prospects of continued migration and usage even after the pandemic (Tvenge \& Martinsen, 2018). Online learning systems allow students to take courses and attend classes and enable instructors to deliver lessons effectively and assess students comfortably, even from home. EFL courses are an example of these courses that had already integrated LMS long before the COVID-19 pandemic broke out (Ta'amneh, 2020).

On the other hand, those who had transferred learning to virtual platforms were less impacted by the dawn of the global shutdown. However, the pandemic forced educational institutions to take LMS systems seriously as they had no better choice (Mahyoob, 2020). Teachers are now using them to improve the learning atmosphere by creating fun that builds an engaging educational environment, stimulates learner attention and interest in the subject, and ensures quicker knowledge synthesis (Aldosari \& Mekheimer, 2013; Beard, 2017; Butnaru et al., 2021; El-Masri \& Tarhini, 2017; Nkonki \& Ntlabathi, 2016). Thus, according to Mohsen and Shafeeq (2014), the migration into online knowledge transfer was principally caused by the often outdated, boring, and lustre-lacking traditional teaching and learning system. Before now, teachers often face difficulties motivating and reviving student interest in their classes, but the advent of flexible remote and LMS-based tools such as Blackboard technology now ease teaching and learning (Ayres, 2002). In addition, new technology-oriented EFL courses are correcting the previous bottlenecks associated with distance learning and educational collaboration through various techniques (Khafaga, 2021). One sustainable approach to easing teaching and learning is the adoption of Blackboard teaching and learning technology, 
whose positive impacts surpass few challenges associated with the tool. Contemporary research regarding the effectiveness of technology tools in EFL courses has shown that Blackboard technologies are helpful and highly effective in teaching English, especially in providing transparent sources of accurate, proper speech in both the oral and written form (Han \& Ellis, 2019; Shamoail, 2005). Aside from well-established LMS systems, many free digital tools are integrated into modern e-learning technologies such as YouTube ${ }^{\circledR}$, Google Docs, Google Meet, Zoom, or Microsoft Teams to ensure efficiency (Tawalbeh, 2018).

With digital learning developments set to grow exponentially over the coming years, educational institutions are rapidly revamping their courses to suit students' requirements growing up in a digital era (Dayag, 2018; Eldridge, 2014; Vo et al., 2017; Webb, 2020). EFL teaching process is moving towards this standard at a faster rate. They create online platforms where students can build constructive relationships with their teachers and colleagues. This is because it is believed that such digital platforms are also considered to be more interactive, which can help develop language skills (Bower et al., 2017). Notwithstanding the quick advancement in adopting flexible remote learning methodologies, it is essential to note the cost of using LMS and the technological gaps created due to the development and improvement of such systems. Thus, in a bid to cite the benefits of using virtual technologies in teaching English, previous literature had often overlooked the consequences of digital learning likewise its challenges (Kassem, 2018). Consequently, as virtual knowledge acquisition evolves, stakeholders in the teaching and learning of English should consider the cost of tools chosen, the rate of knowledge assimilation of the students, cultural barriers, and the prior digital gap in existence (Ali, 2017). LMS technology also helps students have augmented reality experiences like their real-life classroom experiences (Almoeather, 2020). A critical analysis will ensure that the best technology is adopted and the most flexible approach to teaching and learning English implemented (Ismail \& Salih, 2018).

\subsection{Overview of Blackboard Learning Technology}

With the Blackboard learning technology development, teaching and learning have been eased, and outcomes maximised across the educational sector and beyond (Rahmatullah, 2021). Research shows that students and teachers now interact effortlessly using integrated services and media such as teleconferencing, assignments, discussion groups, tests, and video conferencing, promoting creativity and innovation (Motlhaka, 2020). The Blackboard technology was invented to ensure flexibility in digital learning while promoting customisation and flexibility of learning experiences (Omar \& Al-Musabi, 2017). Today, this technology quickly replaces regular face-to-face classes and other methods initially used in teaching and learning. In addition, this technology possesses numerous functions that enable especially English language students to collaborate better and ideas seamlessly (Julian et al., 2019). Above all, the technology expertly emulates the regular classroom while improving the overall experience and revamping the entire teaching and learning processes save time and resources (Banafi, 2018). By implication, English teachers who instruct learners using Blackboard technology can easily create their online courses and plan their lessons effortlessly (Alsadsani, 2020). They can also track their schedules and deliver exciting lectures that students always enjoy working at their homes and offices (Al-Nofaie, 2020).

Furthermore, recent studies indicate a rise in the use of this tool because it saves people the time of walking to classrooms every day under road traffics and accidents and offers them the flexibility of choosing how lessons are delivered (Hamad, 2017). As a result, students and teachers can learn and teach comfortably at their convenience (Al-Nofaie, 2020). Apart from the ability of Blackboard to save energy and cost, it provides an avenue for teachers and students to maximise their time better as they now can better schedule their teaching and learning plans. Moreover, teachers can assign students virtually while enabling students to collaborate as teams in solving given problems.

The Blackboard technology can enable instructors and learners to share resources like audio, files, text, image, and videos, thereby providing multiplicities of teaching and learning and communication options (Khafaga, 2021). Furthermore, modules are organised into folders and streams of lessons with well-articulated descriptions and syllabus to enhance learning. Thus, one can quickly assess and grade students effectively (Amer, 2020). However, no matter the enduring benefits of the blackboard approach in teaching and learning English, more enhancements are essential to enable students who learn English to understand and synthesise knowledge quickly. To achieve this, the technology should incorporate data science, artificial intelligence and, machine learning to enhance speech mechanisms and enliven the entire learning process (Albakri \& Abdulkhaleq, 2021). If combined with blackboard teaching and learning technologies, modern speech recognition tools and amplified reality technologies can proffer sustainable solutions to online learning, thereby offering excellent experiences to instructors and students alike. However, most past research and literature vehemently doubt the possibility of blackboard technology in solving 
critical impediments to borderless teaching and learning (Al Meajel \& Sharadgah, 2018). They mainly argue that the cost of these technologies is a significant barrier. At the same time, economic imbalances across different regions of the world coupled with political instability will hinder the accelerated development of higher-performing blackboard technologies (Amer, 2020).

\subsection{Trends in the Application of Blackboard Technology in Teaching and Learning English}

Educational institutions are hastily making heavy investments into different LMS tools to offer top-tier e-learning services to varieties of learners spread all over the world (Gördeslioğlu \& Yüzer, 2019). However, for these tools to become effective, appropriate support and coaching must be provided to students and teachers to utilise them effectively (Al-Fadhli, 2008; Liaw, 2008; Sun et al., 2008).

LMS systems like Blackboard technology offer English language teachers multiple online course management features, which enable them to issue announcements and grade tests and quizzes with ease (Ngai et al., 2007; Shamoail, 2005). On the other hand, it allows learners to take exercises comfortably and learn at their paces. So, LMS systems are a boon for students as they have augmented their online exchanges with teachers. Instructors are now motivating students to be actively involved in their learning process instead of falling back into a passive, endemic role in traditional classrooms (Joseph, 2012; Mahyoob, 2020; Tella, 2012). However, when it comes to users' perceptions, Servonsky et al. (2005) studied the challenges blocking the broader adoption of Internet-based Blackboard technology by higher education institutions and universities. In their study, the issues faced by students using LMS in various technical aspects such as affordability, time management, and comprehension have often been outlined even by preceding authors and researchers. Hence, the need for increased accuracy of the teaching materials and increased preparation time compared to traditional classroom processes is indispensable (Huang et al., 2021). Hong et al. (2003) carried out a comprehensive exploration of how successful an Internet-based instruction and learning environment can be in forming a positive attitude towards utilising Internet-based services to integrate EFL learning strategies in students at the undergraduate level. The study's findings critically revealed that undergraduates were positively inclined to utilise the Internet for learning purposes and reported a positive response to the Internet-based EFL learning environment, considering the highly effective and supportive (Hong et al., 2003). However, the report failed to cite the impediments to the utilisation of virtual tools in the learning of English, which would have offered insights for improvements. Therefore, the inability of past literature to present a precise, concise, and consistent analysis of the merits, demerits, and barriers to applying Blackboard technologies in learning undermines most past research, thereby providing grounds for further research and investigations (Khan, 2017).

However, from a technical standpoint, Blackboard happens to be among the most widely used Internet-based LMS systems available today. Roughly 17,000 educational institutes in 100 countries use Blackboard technology. As stated by 'Times Higher Education World Reputation Ranking', Blackboard tools are purportedly utilised by $80 \%$ of the world's topmost academic institutions. For instance, $75 \%$ of US universities and schools use the services of this technology, which makes the US one of the top countries that use Blackboard, followed by the UK, Canada, Australia, and India. In the Middle East, Blackboard Inc. has been recently licensed by more than thirty top institutes from 8 countries (Alamer, 2020; Al-Nofaie, 2020; Alokluk, 2018; Nkonki \& Ntlabathi, 2016). Because of its advanced tech integrations, user-friendliness, and flexibility in application, this tool may offer lasting solutions to virtual learning. For example, it contains numerous administrative instruments, which both teachers and students can use. Blackboard also allows enhanced access to learning resources, allowing learners to retrieve their course materials and submit assignments within a deadline (Fageeh \& Mekheimer, 2013). Blackboard also offers two kinds of feedback in the form of teacher-initiated feedback (Heirdsfield et al., 2011). Teachers respond to submissions created by students and with an automatic feedback option where the test manager feature in the platform is used to host exams and quizzes (Al-Naibi et al., 2015; Bradford et al., 2007). The technology comes with numerous other functions, including an innovative correspondence feature for students and teachers, announcements, email, discussion panels, virtual classrooms, etc. (Heirdsfield et al., 2011).

Currently, the online digital learning field has become the subject of numerous studies seeking to understand the overall effectiveness of LMS tools, especially in teaching and learning English. To this effect, Blackboard technology continues to attract more attention than e-learning technologies owing to its enhanced features (Tseng, 2020). Multiple studies seek to understand the impact of Blackboard tools, especially concerning the perceptions held by teachers and students, which have all arrived at varying results. For example, a study comparing Moodle and Blackboard revealed that users preferred the former to its innovative Mode framework, which allowed Moodle to integrate seamlessly with the course design compared to its competition. Still, it lacked the lustre and diversity of Blackboard (Carvalho et al., 2011). LMS systems like Blackboard Technology now enjoy widespread adoption, 
especially in Europe and North America, where higher institutions emphasise their usage due to their advanced technological atmosphere, unlike less technologically developed regions of the world (Gördeslioğlu \& Yüzer, 2019).

On the other hand, Africa and Asia are yet to reach similar levels of adoption of the Blackboard learning tools or similar ones for numerous reasons (Paechter et al., 2010). First, the challenges posed by poor economic conditions in those regions prevent schools and students alike from investing in digital technology for teaching and learning English. Thus, they resort to the traditional classroom methods of learning. Secondly, many countries in the Middle East and North Africa have yet to adopt blackboard technology in teaching and learning English. Moreover, political instability, religious barriers, discrimination, and civil strife in places like Pakistan and Afghanistan may hinder teachers and students from adopting Blackboard in teaching and learning the English language (Ilyas, 2018).

In essence, the failure to critically analyse and sectionalise the impacts and challenges of using digital tools in teaching English undermines previous literature and research works. Therefore, it should be resolved in any subsequent studies. Nevertheless, Comber et al. (2010) studied LMS systems' impact on the learning process by researching Frontier, Moodle, and CEWebS. The study concluded that implementing a detected blended learning scenario effectively depended on the appropriate classification scheme chosen. Similarly, Al Meajel \& Sharadgah (2018) is a more recent study examining today's various digital learning systems. They studied the obstacles to utilizing the Blackboard system in the teaching and learning process from the perceptive of 117 faculty members. They found that 'technological barriers' and 'institutional barriers' remained the most greatly acknowledged barriers.

\subsection{Indicators of Effective Application of Blackboard Technology in Teaching-Learning English}

Based on research, numerous indicators can be used to measure the overall effectiveness of Blackboard technology (Tsai, 2019). One of them is the long run time this technology has been operating for while remaining highly usable and accessible - a claim supported by numerous authors (Alokluk, 2018; Fageeh \& Mekheimer, 2013; Liaw, 2008; Nkonki \& Ntlabathi, 2016). Other indicators used to measure the overall usefulness include the impact made on the interactions between end-users such as teachers and their students, ease of use, and accessibility. Landry et al. (2006) used indicators like the degree of utilisation, ease of usage, the value offered, and general perception of the users regarding the learning environment to measure student response to Blackboard tech. In general, the conclusions obtained from various authors and their studies reveal that Technology Acceptance Model utilisation has a positive reception from end-users. Caputi and Garrido's (2015) demonstrated that the perceived execution component could be split into perceived ease of usage and quality.

It is also critical to consider the context of EFL teaching programmes as the overall quality of the system and service has a significant impact on general intelligibility (El-Sawy, 2018; Fageeh \& Mekheimer, 2013). This factor tends to be highly crucial for EFL people since they may not be aware of certain expressions that must be visualised and heard clearly for better understanding. Buzzetto-More (2008) concluded that students considered course management systems like the Blackboard e-learning system to be a net positive and immensely helpful in enhancing their grasp of the course content. The latest academic literature reveals that Blackboard technology enjoys four distinct advantages: freedom to ask questions and make statements freely, increased access to course materials online, freedom to determine their lesson schedules, and independence from time constraints. Additionally, it is also noted that both teachers and students could gain more educational opportunities by using such LMS systems (Bouhnik \& Marcus, 2006; Fageeh \& Mekheimer, 2013; Farooq et al., 2017; Joseph, 2012).

Blackboard has gone on to be among the world's most widely adopted course management platforms. It is used for both online and offline teaching purposes. Teachers and students in different EFL courses stated that Blackboard LMS was beneficial for their needs (Bradford et al., 2007; Heirdsfield et al., 2011). Ali (2017) revealed that Blackboard utilisation provided additional motivation to EFL students. However, this case study came across mixed results, with some students agreeing that Blackboard motivated them further to study English, whereas others felt demotivated by the same platform. The study stated that while Blackboard had a huge widespread impact, the actual results were not conclusive enough to tilt either way. Besides, Alamer (2020) said that Blackboard system usage helped students grasp management and organisational skills faster, thus making them better at their studies. However, Blackboard had no direct impact on improving the English language acquisition skills of the students (Demir et al., 2021). This study also stated that Blackboard had little effect on the performance and attitudes of students engaged in vocabulary acquisition, thus pointing to the limits of Blackboard technology.

Mohsen and Shafeeq (2014) concluded that EFL instructors were positively inclined towards apps like Blackboard. Most of them viewed it as a valuable platform for tremendous success to provide better value to their students. Mohammad-Hussein (2016) concluded that EFL courses that used Blackboard effectively explained EFL course content better than conventional teaching systems. It offered students more opportunities to interact with their course Published by Sciedu Press 
materials, teachers, activities, and peers. Alturise (2020) conducted a study regarding the satisfaction levels of teachers and students who used the Blackboard platform as part of their online learning process. While the platform was hailed for its innovative nature, the end-users agreed that more improvements were needed to increase the adoption of virtual learning applications. This was especially true for EFL courses. However, the usage of Blackboard technology was primarily seen as an administrative concern, not something that would change the existing pedagogy (El-Sawy, 2018; Liaw, 2008; Mohsen \& Shafeeq, 2014). Tawalbeh (2018) stated that while teachers appreciated Blackboard technology, they considered Blackboard to have several aspects that needed improvement. Usage rates were also considerably low.

Additionally, Fageeh and Mekheim (2013) revealed that students had an increasingly positive attitude towards Blackboard technology as they spent more time with the system. Online peer reviews and discussions through Blackboard were found to boost student learning and positive learning interactions. Fageeh and Mekheim (2013) also stated that Blackboard communication promoted positive attitudes like increased participation, collaboration, and productivity. Another study concluded that students using Blackboard technology were far more motivated than conventional learning methods (Ali, 2017).

\subsection{Barriers to the Adoption of Blackboard Technology}

The COVID-19 pandemic caused institutions of higher learning to rush to adopt LMS systems to ensure uninterrupted education (Alkhaldi \& Abualkishik, 2019). Since institutions had to switch to a fully online distance learning mode, video chatting tools like Blackboard Collaborate Ultra were explicitly designed for end-users in the educational field to communicate in real-time. Like Google Meet or Zoom, this platform offered top-tier audio and video quality during online communications, which is essential for the teaching-learning process (Al-Naibi et al., 2015).

Although Blackboard has a highly positive influence on both teachers and students regarding EFL courses (Abdellatif \& Alsharidah, 2020; Alokluk, 2018), no technology remains without barriers. Servonsky and Bretha (2005) identified numerous challenges that Blackboard was yet to solve, such as setting aside more time to plan the course materials and lecture content. Activities like reviewing, researching, or downloading assignments, making alterations, references, and reposting important documents made the process cumbersome. A year later, Bouhnik and Marcus (2006) also revealed some essential shortcomings of the Blackboard platform, such as the absence of a strict framework that facilitated learning measures among the students and overt reliance on ineffective distance learning methods.

Likewise, Blackboard did not instil any more creativity in EFL teachers or students than conventional teaching methods (Lane, 2008; Al-Naibi et al., 2015). Even experienced faculty members struggled with using such tools and spent more time dealing with simple technological challenges instead of using that time to accomplish their teaching objectives. As a result, experienced teachers generally use Blackboard only for email, unimportant grading duties, and presenting static visual learning content to students (Nkonki \& Ntlabathi, 2016).

In the field of EFL teaching, Ilyas (2018) revealed that although EFL teachers and students are conscious of the effectiveness of Blackboard, they lack willingness for change. Consequently, He asserted "readiness or acceptance for change is a multidimensional variable influenced by factors such as context, change beliefs, individual differences and resistance to change" (p. 216). The effect of cultural background on change was acknowledged by Al-khresheh (2020), who stated that the process of EFL teaching and learning is relatively affected by some cultural barriers that lead to resistance to change. In the same vein, El-Sawy (2018) pointed out that the in-built chat box was found to have accessibility issues with broken autocorrect features, which was troublesome for EFL learners. Susanti (2020) concluded that EFL students were found to face difficulties engaging in cooperative activities or presentations, which negatively affected their cognitive engagement. They also suffered from anxiety issues as they were scared to commit further mistakes by accident, causing them to withdraw into silence and passivity in online classes. While students displayed a high level of behavioural engagement, their emotional and cognitive engagement was deemed not quite positive. The findings are believed to contribute to a better understanding of the engagement of EFL students in computer-generated classes. In another study during the coronavirus pandemic, Khafaga (2021) revealed that while both teachers and students faced challenges due to the unique circumstances of the pandemic, Blackboard technology usage was found to boost learning and language acquisition.

Most Blackboard problems pertain to annoying or glitchy technology features that hampered user convenience or low usage levels. Self-directed online learning environments are considered inadequate at high-level discussions and communications, which bogged down the whole learning process. Student-teacher interactions are believed to be somehow unsatisfactory for the most part and that both sets of end-users (teachers \& students) had to spend Published by Sciedu Press 
additional time on their lessons. More preparations had to be made to correctly grasp the content taught via Blackboard, which could have been productively used for other purposes. These problems were acknowledged in several studies (e.g., Aladsani, 2020; Alamer, 2020; Albakri \& Abdulkhaleq, 2021; Alkhaldi \& Abualkishik, 2019).

Several reports state that teachers only adopt online platforms when they have no other choice, not out of their own free will. Hence, the adoption of online learning platforms comes down to static and administrative decisions instead of being made to improve the existing pedagogy (Lo, 2020; Mahyoob, 2020).

\section{Limitations and Recommendations for Future Research}

The results cannot be generalized because it is a review study conducted based on a thorough analysis of previous and current literature about the impact of Blackboard technology on the EFL teaching-learning process in general. To better understand the COVID-19 impact on the use of Blackboard, further research is encouraged to carry out quantitative studies on teachers and students' perceptions especially after two years now of the pandemic. Furthermore, a comparative study between Blackboard and other technologies in the same area would be good for future research.

\section{Conclusion}

It is important to note that acquiring English language skills is a high priority, especially in today's globalised economy. To remain competitive in today's employment market, it has become practically mandatory for students to use English confidently. Teaching EFL virtually due to COVID-19 has made the process a bit difficult. Therefore, there was a need to carry out a comprehensive examination of the impact of digital technology such as Blackboard on teaching and learning English.

It is evident from the previous literature that Blackboard has a good effect on the EFL teaching-learning process, based on end-user perceptions. By providing substantial teaching benefits to students and teachers alike, Blackboard has unquestionably added a new-fangled dimension to education. It helped in improving the communication process between teachers and students. While users reported a high percentage of positive experiences with effectiveness as far as the Blackboard system was concerned, some issues and niggles are slowing down its adoption. Blackboard technology is consistent, reliable, and familiar to most teachers and students, which explains its popularity in higher institutions. While better alternatives might exist, institutions are reluctant to alter the existing normal, especially since moving to an updated and improved system can be uncertain and costly. Thus, Blackboard technology is a net positive in planning, outlining, preparing, delivering, and assessing different English courses as per both students and teachers.

However, it must be also noted that Blackboard is compatible with external communication apps like Zoom and Google Meets, which comes with several advantages. However, uploading, sharing, and submitting documents via Blackboard can also be an annoying experience, as revealed by a few studies. When all these factors are considered, it is evident that Blackboard suffers from accessibility issues, making it seem overpriced. While many EFL teachers and students are most comfortable with Blackboard, this may be because of their familiarity with the system over the years, not necessarily because it is the best platform around.

\section{Recommendations}

The video and audio quality of communications between teachers and students via the Blackboard platform must be considered due to its importance in influencing the overall grasp of students over the language. Valuable expressions must be communicated concisely with no scope for misinterpretation by teachers to their students.

However, while the advantages outweigh the disadvantages, there are massive challenges to utilising this technology effectively that need to be resolved quickly. First, to improve the utilisation of the technology in teaching and learning, it is paramount to integrate the tool with other advanced technologies such as Google meet, Microsoft Teams, and social media platforms to enhance user experiences and ensure flexibility in its application. Secondly, Blackboard should be affordable for both teachers and students to ensure it is used globally, especially in developing countries struggling with economic challenges. Finally, as the development of Blackboard has created avenues for seamless teaching and learning, evidence indicates that it will provide long-term solutions to modern-day digital learning. However, the usage of Blackboard requires additional preparation from both teachers and students, which might hamper their productivity. So, as teachers and students use Blackboard to collaborate digitally, it is essential to enhance and integrate this technology to incorporate flexibility in teaching and learning English.

\section{References}

Abdalla, I. (2005). Evaluating effectiveness of Blackboard system using TAM framework: A structural analysis 
approach. In G. Richards (Ed.), Proceedings of E-Learn: World Conference on E-Learning in Corporate, Government, Healthcare, and Higher Education 2005 (pp. 477-481). Chesapeake, VA: Association for the Advancement of Computing in Education (AACE).

Abdellatif, M. S., \& Alsharidah, M. A. (2020). Academic buoyancy as a predicator of the Prince Sattam Bin Abdul-Aziz university students' attitudes towards using the blackboard system in e-Learning. Multicultural Education, 6(5), 204-216.

Al Meajel, T. M., \& Sharadgah, T. A. (2017). Barriers to using the Blackboard system in teaching and learning: Faculty perceptions. Technology, Knowledge and Learning, 23, 351-366. https://doi.org/10.1007/s10758-017-9323-2

Aladsani, H. K. (2020). A narrative approach to university instructors' stories about promoting student engagement during COVID-19 emergency remote teaching in Saudi Arabia. Journal of Research on Technology in Education, O(0), 1-17. https://doi.org/10.1080/15391523.2021.1922958

Alamer, H. A. (2020). Impact of using Blackboard on vocabulary acquisition: KKU students' perspective. Theory and Practice in Language Studies, 10(5), 598-603. https://doi.org/10.17507/tpls.1005.14

Albakri, A., \& Abdulkhaleq, A. (2021). An interactive system evaluation of blackboard system applications: a case study of higher education. IGI Global Publisher of Timely Knowledge. https://doi.org/10.4018/978-1-7998-4846-2.ch009

Aldosari, H., \& Mekheimer, M. (2013) The bandwagon effect in the adoption of e-learning systems in language learning - an appraisal. GSTF Journal on Computing, 2(4), 61-81.

Al-Fadhli, S. (2008). Students' perceptions of e-learning in Arab society: Kuwait University as a case study. E-Learning and Digital Media, 5(4), 418-428. https://doi.org/10.2304/elea.2008.5.4.418

Ali, J. K. M. (2017). Blackboard as a motivator for Saudi EFL students: A psycholinguistic study. International Journal of English Linguistics, 7(5), 144-151. https://doi.org/10.5539/ijel.v7n5p144

Alkhaldi, A. N., \& Abualkishik, A. M. (2019). Predictive Factors for the intention to adopt a mobile Blackboard course management system: the case study of university of Hai'l in Saudi Arabia. Journal of Science and Technology, 12(19), 1-12. https://doi.org/10.17485/ijst/2019/v12i19/140855

Al-khresheh, M. (2020). The impact of cultural background on Listening comprehension of Saudi EFL students. Arab World English Journal, 11(3), 349-371. https://doi.org/10.24093/awej/vol11no3.22

Al-khresheh, M. H. (2021). Reconceptualising the elements of effective English language teaching through the lens of pandemic induced online teaching: An exploratory study of Jordanian EFL Teachers' Perceptions. Asian EFL Journal, 28(2), 61-97.

Al-Mashaqbeh, I. F. (2009). The use of Blackboard software as a course delivery method. Journal of Educational \& Psychological Sciences, 10(3), 12-28. https://doi.org/10.12785/JEPS/100311

Almoeather, R. (2020). Effectiveness of blackboard and Edmodo in self-regulated learning and educational satisfaction. Turkish Online Journal of Distance Education, 21(2), 126-140. https://doi.org/10.17718/tojde.728140

Al-Naibi, S. A., Madarsha, K. B., \& Ismail, N. A. (2015). Blackboard use by faculty members in the colleges of applied sciences in the Sultanate of Oman. International Journal for Innovation Education and Research, 3(4), 26-40. https://doi.org/10.31686/ijier.vol3.iss4.345

Al-Nofaie, H. (2020). Saudi university students' perceptions towards virtual education during COVID-19 pandemic: a case study of language learning via Blackboard. Arab World English Journal, 11(3), 4-20. https://doi.org/10.24093/awej/vol11no3.1

Alokluk, J. (2018). The effectiveness of Blackboard system, uses and limitations in information management. Intelligent Information Management, 10, 133-149. https://doi.org/10.4236/iim.2018.106012

Alokluk, J. A (2018). The effectiveness of Blackboard system, uses and limitations in information management. Intelligent Information Management, 10, 133-149. https://doi.org/10.4236/iim.2018.106012

Al-Qahtani, M. H. (2019). Teachers' and students' perceptions of virtual classes and the effectiveness of virtual classes in enhancing communication skills. Arab World English Journal, 1(Special Issue: The Dynamics of EFL in Saudi Arabia), 223-240. https://doi.org/10.24093/awej/efl1.16 
Al-Senaidi, S., Lin, L., \& Poirot, J. (2009). Barriers to adopting technology for teaching and learning in Oman. Computers \& Education, 53(3), 575-590. https://doi.org/10.1016/j.compedu.2009.03.015

Alsowayegh, N. H., Bardesi, H. J., Garba, I., \& Sipra, M. A. (2019). Engaging students through blended learning activities to augment listening and speaking. Arab World English Journal, 5(1), 267-288. https://doi.org/10.31235/osf.io/hqcgy

Alturise, F. (2020). Evaluation of the Blackboard learning management system for full online courses in western branch colleges of Qassim University. International Journal of Emerging Technologies in Learning, 15(15), 33-50. https://doi.org/10.3991/ijet.v15i15.14199

Amer, M. E. (2020). The Impact of Distance Education on Learning Outcome in Computer Skills Course in Prince Sattam bin Abdulaziz University: An Experimental Study. Journal of Curriculum and Teaching, 9(4), 1-9. https://doi.org/10.5430/jct.v9n4p1

Ayres, R. (2002). Learner attitudes towards the use of CALL. Computer Assisted Language Learning, 15, $241-249$. https://doi.org/10.1076/call.15.3.241.8189

Azarian, R. (2011). Potentials and limitations of comparative method in social science, International Journal of Humanities and Social Science, 1(4), 113-125.

Babbie, E. (2005). The basic of social research. Canada: Wadsworth Publishing Company.

Bacher-Hicks, A., Goodman, J., \& Mulhern, C. (2020). Inequality in household adaptation to schooling shocks: COVID-induced online learning engagement in real time. NBER working paper series. https://doi.org/10.3386/w27555

Baker, W., \& Watson, J. (2014). Mastering the online Master's: developing and delivering an online MA in English language teaching through a dialogic-based framework. Innovations in Education and Teaching International, 51(5), 483-496. https://doi:10.1080/14703297.2013.796712

Banafi, N. H. (2018). The impact of blended learning on medical students' engagement and achievement with English language terminology: a case study of teachers' and students' self-efficacy and attitudes at Jazan University Saudi Arabia. University of Limerick.

Beard, L. H. (2017). 'Incentivized reading': Using an online VLE to measure engagement and attainment in student learning. International Journal for Innovation Education and Research, 5(11), 74-86. https://doi.org/10.21125/edulearn.2017.0006

Bouhnik, D., \& Marcus, T. (2006). Interaction in distance-learning courses. Journal of the American Society Information Science and Technology, 57(3), 299-305. https://doi.org/10.1002/asi.20277

Boulton, C. A., Kent, C., \& Williams, H. T. (2018). Virtual learning environment engagement and learning outcomes at a 'bricks-and-mortar' university. Computers \& Education, 126, 129-142. https://doi.org/10.1016/j.compedu.2018.06.031

Bower, M., Lee, M. J., \& Dalgarno, B. (2017). Collaborative learning across physical and virtual worlds: Factors supporting and constraining learners in a blended reality environment. British Journal of Educational Technology, 48(2), 407-430. https://doi.org/10.1111/bjet.12435

Bradford, P., Porciello, M., Balkon, N., \& Backus, D. (2007). The Blackboard learning system: The be all and end all in educational instruction? Journal of Educational Technology Systems, 35, 301-314. https://doi.org/10.2190/X137-X73L-5261-5656

Braver, S. L., Thoemmes, F. J., \& Rosenthal, R. (2014). Continuously cumulating metaanalysis and replicability. Perspectives on Psychological Science, 9, 333-342. https://doi.org/10.1177/1745691614529796

Bukhari, S. S. F., \& Basaffar, F. M. (2019). EFL learners' perception about integrating blended learning in ELT. Arab World English Journal, 5(1), 190-205. https://doi.org/10.24093/awej/call5.14

Butler, D. L., \& Sellbom, M. (2002). Barriers to adopting technology for teaching and learning. Educause Quarterly, $8(2), 22-28$

Butnaru, G. I., Nita, V., Anichiti, A., \& Brinza, G. (2021). The effectiveness of online education during Covid 19 Pandemic: A comparative analysis between the perceptions of academic students and high school students from Romania. Sustainability, 13, 5311. https://doi.org/10.3390/su13095311

Buzzetto-More, N. (2008). Student perceptions of various e-learning components. Interdisciplinary Journal of 
E-Learning and Learning Objects, 4(1), 113-135. https://doi.org/10.28945/3204

Caputi, V., \& Garrido, A. (2015). Student-oriented planning of e-learning contents for Moodle. Journal of Network and Computer Applications, 53, 115-127. https://doi.org/10.1016/j.jnca.2015.04.001

Carrillo, C., \& Flores, A. M. (2020). COVID-19 and teacher education: a literature review of online teaching and learning practices. European Journal of Teacher Education, 43(4), 466-487. https://doi.org/10.1080/02619768.2020.1821184

Carvalho A., Areal, N., \& Silva, J. (2011). Students' perceptions of Blackboard and Moodle in a Portuguese university. British Jounal of Educational Technology, 42(5), 824-841. https://doi.org/10.1111/j.1467-8535.2010.01097.x

Coates, H. (2007). A model of online and general campus-based student engagement. Assessment \& Evaluation in Higher Education, 32(2), 121-141. https://doi.org/10.1080/02602930600801878

Coates, H., James, R., \& Baldwin, G. A. (2005). Critical examination of the effects of learning management systems on University teaching and learning. Tertiary Education and Management, 11, 19-36. https://doi.org/10.1007/s11233-004-3567-9

Comber, A. J., Carver, S., Fritz, S., McMorran, R., Washtell, J. \& Fisher, P. (2010). Different methods, different wilds: evaluating alternative mappings of wildness using Fuzzy MCE and Dempster Shafer MCE. Computers, Environment and Urban Systems, 34, 142-152. https://doi.org/10.1016/j.compenvurbsys.2009.10.006

Dayag, J. D. (2018). EFL virtual learning environments: Perception, concerns and challenges. Teaching English with Technology, 16(4), 20-33.

Demir, F., Bruce-Kotey, C., \& Alenezi, F. (2021). User experience matters: does one size fit all? Evaluation of learning management systems. Technology, Knowledge and Learning. https://doi.org/10.1007/s10758-021-09518-1

Demirkol-Orak, S., \& İnözü, J. (2021). Teachers' awareness and actual practices of 21st century learning and innovations skills. International Online Journal of Education and Teaching, 8(2), 975-997.

Eldridge, B. (2014). Exploring faculty adoption and utilization of Blackboard at a community college in the Kentucky Community and Technical College System. (Doctoral dissertation), University of Kentucky, USA.

El-Masri, M., \& Tarhini, A. (2017). Factors affecting the adoption of e-learning systems in Qatar and USA: Extending the Unified Theory of Acceptance and Use of Technology 2 (UTAUT2). Educational Technology Research and Development, 65, 743-763. https://doi.org/10.1007/s11423-016-9508-8

El-Sawy, H. (2018). Flipping EFL university classes with Blackboard system. English Language Teaching, 11(2), 31-34. http://doi.org/10.5539/elt.v11n2p31

Fageeh, A., \& Mekheimer, M. A. A. (2013). Effects of Blackboard on EFL academic writing and attitudes. Jaltcall journal, 9(2), 169-196. https://doi.org/10.29140/jaltcall.v9n2.154

Farooq, M. U., Riaz, K., \& Javid, C. Z. (2017). Impact of emotional intelligence on academic achievement of English language learners. Journal of Social Sciences and Humanities, 25(2), 2-34.

Garside, R. (2014). Should we appraise the quality of qualitative research reports for systematic reviews, and if so, how? Innovation. The European Journal of Social Science Research, 27, 67-79. https://doi.org/10.1080/13511610.2013.777270

Gay, L., \& Airasian, P. (2005). Educational Research: Competencies for Analysis and Application (8th ed.). Upper Saddle River, New Jersey, Columbus, Ohio: Merrill Prentice Hall.

Glasziou, P. (2001). Systematic reviews in health care: A practical guide. New York, NY: Cambridge University Press. https://doi.org/10.1017/CBO9780511543500

Gördeslioğlu, N. G., \& Yüzer, T. E. (2019). Using LMS and blended learning in designing a course to facilitate foreign language learning. KnE Social Sciences, 3(24), 10-25. https://doi.org/10.18502/kss.v3i24.5164

Hamad, M. M. (2017). Pros \& cons of using Blackboard Collaborate for blended learning on students' learning outcomes. Higher Education Studies, 7(2), 7-16. https://doi.org/10.5539/hes.v7n2p7

Han, F., \& Ellis, R. A. (2019). Identifying consistent patterns of quality learning discussions in blended learning. The Internet and Higher Education, 40, 12-19. https://doi.org/10.1016/j.iheduc.2018.09.002 
Heirdsfield, A., Walker, S., Tambyah, M., \& Beutel, D. ((2011). Blackboard as an online learning environment: What do teacher education students and staff think? Australian Journal of Teacher Education, 36(7), 1-16. https://doi.org/10.14221/ajte.2011v36n7.4

Hong, K. S., Ridzuan, A. A., \& Kuek, M. K. (2003). Students' attitudes toward the use of the Internet for learning: A study at a university in Malaysia. Educational Technology \& Society, 6(2), 45-49.

Hrastinski, S. (2009). A theory of online learning as online participation. Computers and Education, 52, 78-82. https://doi.org/10.1016/j.compedu.2008.06.009

Huang, J., Wang, Y., \& Teng, F. (2021). Understanding changes in teacher beliefs and identity formation: A case study of three novice teachers in Hong Kong. Teaching Education, 32(2), 193-207. https://doi.org/10.1080/10476210.2019.1693535

Ilyas, M. (2018). Investigating readiness for acceptance of change for the adoption of Blackboard LMS at Prince Sattam Bin Abdulaziz University, Saudi Arabia. International Journal of Education and Practice, 6(4), $216-226$. https://doi.org/10.18488/journal.61.2018.64.216.226

Ismail, A. M., \& Salih, A. A. (2018). The impact of Blackboard LMS on teaching research method course for technology studies graduate students at the Arabian Gulf University. International Journal of Information and Education, 8(2), 81-87. https://doi.org/10.18178/ijiet.2018.8.2.1017

Joseph, J. (2012). The barriers of using education technology for optimizing the educational experience of learners. Procedia-Social and Behavioural Sciences, 64, 427-436. https://doi.org/10.1016/j.sbspro.2012.11.051

Julian, C. C., Toni, D., \& Sarah, K. (2019). Lecturers' perceptions and experiences of Blackboard Collaborate as a distance learning and teaching tool via Open Universities Australia (OUA). The Journal of Open, Distance and e-Learning, 35(3), 222-235. https://doi.org/10.1080/02680513.2019.1688654

Kassem, M. A. (2018). The effect of using Blackboard on English majors' writing proficiency and attitudes. Journal of Applied Linguistics and English, 7(6), 73-79. https://doi.org/10.7575/aiac.ijalel.v.7n.6p.73

Khafaga, A. (2021). The perception of blackboard collaborate-based instruction by EFL majors/teachers amid COVID-19: A case study of Saudi universities. Journal of Language and Linguistic Studies, 17(Special Issue 2), 1160-1173. https://doi.org/10.17263/jlls.904145

Khan, I. A. (2017). Utilization of different technologies and media in learning writing skill in English: a case study. European Journal of Education Studies, 2(6), 144-156.

Landry, B., Griffeth, R., \& Hartman, S. (2006). Measuring student perceptions of Blackboard using the technology acceptance model. Decision Sciences Journal of Innovative Education, 4(1), 87-99. https://doi.org/10.1111/j.1540-4609.2006.00103.x

Lane, L. M. (2008). Toolbox or trap? course management systems and pedagogy. Educause Quarterly, 31, 4-6.

Larkin, T. L., \& Belson, S., I. (2005). Blackboard technologies: a vehicle to promote students' motivation in physics. Journal of Stem Education: Innovation and Research, 6(1), 14-27.

Liaw, S. (2008). Investigating students' perceived satisfaction, behavioural intention, and effectiveness of e-Learning: a case study of the Blackboard system. Computers \& Education, 51(2), 864-873. https://doi.org/10.1016/j.compedu.2007.09.005

Lin, M. H., Chen, H. G., \& Liu, K. S. (2017). A study of the effects of digital learning on learning motivation and learning outcome. EURASIA Journal of Mathematics Science and Technology Education, 13(7), 3553-3564. https://doi.org/10.12973/eurasia.2017.00744a

Lo N. P. K. (2020) Revolutionising Language Teaching and Learning via Digital Media Innovations. In: Ma W.W., Tong K., Tso W.B.A. (eds) Learning Environment and Design. Educational Communications and Technology Yearbook. Springer, Singapore. https://doi.org/10.1007/978-981-15-8167-0_15

Mahyoob, M. (2020). Challenges of e-Learning during the COVID-19 Pandemic Experienced by EFL Learners. Arab World English Journal, 11(4), 351-362. https://doi.org/10.24093/awej/vol11no4.23

Mohammad-Hussein, H. E. (2016). The effect of Blackboard collaborate-based instruction on pre-service teachers' achievement in the EFL teaching methods course at Faculties of Education for Girls. English Language Teaching, 9(3). https://doi.org/10.5539/elt.v9n3p49

Mohsen, A. M., \& Shafeeq, C. P. (2014). EFL teachers' perceptions on Blackboard applications. English Language 
Teaching, 7(11). https://doi.org/10.5539/elt.v7n11p108

Motlhaka, H. (2020). Blackboard collaborated-based instruction in an academic writing class: sociocultural perspectives of learning. Electronic Journal of e-Learning, 18(4), 337-346. https://doi.org/10.34190/EJEL.20.18.4.006

Ngai, E. W. T., Poon, J. K. L., \& Chan, Y. H. C. (2007). Empirical examination of the adoption of WebCT using TAM. Computers \& Education, 48(2), 250-267. https://doi.org/10.1016/j.compedu.2004.11.007

Nkonki, V., \& Ntlabathi, S. (2016). The forms and functions of teaching and learning innovations on blackboard: substantial or superficial? The Electronic Journal of e-Learning, 14(4), 258-265.

Omar, R., \& Al-Musabi, Z. (2017). The effectiveness of using the BlackBoard mobile learning application. International Educational Journal Specialized, 6(7), 126 -136.

Paechter, M., Maier, B., \& Macher, D. (2010). Students' expectations of, and experiences in e-learning: their relation to learning achievements and course satisfaction. Computers \& Education, 54(1), 222-229. https://doi.org/10.1016/j.compedu.2009.08.005

Poon, J. (2013). Blended learning: an institutional approach for enhancing students' learning experiences. Merlot Journal of Online Learning and Teaching, 9(2), 271-288.

Rahmatullah, I. (2021). Blackboard as online learning management system in Saudi Context: challenges and prospects. Proceedings of the AUBH E-Learning Conference 2021: Innovative Learning \& Teaching - Lessons from COVID-19.

Servonsky, W. L., \& Bertha, L. (2005). Evaluation of blackboards as a platform for distance education delivery. The ABNF Journal, 132-135.

Shamoail, E. (2005). Teachers' perceptions and experiences in adopting Blackboard computer program in a Victorian secondary school: A case study. (Doctoral Dissertation), Victoria University, Australia.

Siddaway, A. P., Wood, A. M., \& Hedges, L. V. (2019). How to do a systematic review: a best practice guide to conducting and reporting narrative reviews, meta-analyses, and meta-syntheses. Annual Review of Psychology, 70. https://doi.org/10.1146/annurev-psych-010418-102803

Snyder, H. (2019). Literature review as a research methodology: An overview and guidelines. Journal of Business Research, 104, 333-339. https://doi.org/10.1016/j.jbusres.2019.07.039

Sousa, M. J., \& Rocha, Á. (2019). Digital learning: Developing skills for digital transformation of organization. Future Generation Computer Systems, 91,327-334. https://doi.org/10.1016/j.future.2018.08.048

Sun, P. C., Tsai, R. J., Finger, G., Chen, Y. Y., \& Yeh, D. (2008). What drives a successful el-earning? An empirical investigation of the critical factors influencing learner satisfaction. Computers \& Education, 50(4), 1183-1202. https://doi.org/10.1016/j.compedu.2006.11.007

Susanti, Y. (2020). The students' engagement in EFL online class. Lingual: Journal of Language and Culture, 10(2). https://doi.org/10.24843/LJLC.2020.v10.i02.p02

Ta'amneh, M. (2020). The effect of blackboard learning on the development of English writing skills among university students. Journal of Education and Practice, 11(19), 83-91.

Tawalbeh, T. I. (2018). EFL instructors' perceptions of Blackboard learning management system (LMS) at university level. English Language Teaching, 11(1). https://doi.org/10.5539/elt.v11n1p1

Tella, A. (2012). System-related factors that predict students' satisfaction with the blackboard learning system at the University of Botswana. African Journal of Library, Archives and Information Science, 22(1), 41-52.

Tsai, C. C. (2019). A study of Taiwanese elementary school English as a foreign language: teachers' beliefs, advantages, and difficulties of using interactive whiteboards. Asia-Pacific Social Science Review, 19(4), 87-99.

Tschand, M., Mayer, B., \& Sorkoa, S. R. (2020). An interdisciplinary digital learning and research factory: The Smart Production Lab. Procedia Manufacturing, 45, 491-496. https://doi.org/10.1016/j.promfg.2020.04.061

Tseng, H. (2020). An exploratory study of students' perceptions of learning management system utilisation and learning community. Research in Learning Technology, 28(2423), 1-18. https://doi.org/10.25304/rlt.v28.2423

Tvenge, N., \& Martinsen, K. (2018). Integration of digital learning in industry. Procedia Manufacturing, 23, 261-266. https://doi.org/10.1016/j.promfg.2018.04.027

Published by Sciedu Press 
Vo, H. M., Zhu, C., \& Diep, N. A. (2017). The effect of blended learning on student performance at course-level in higher education: A meta-analysis. Studies in Educational Evaluation, 53, 17-28. https://doi.org/10.1016/j.stueduc.2017.01.002

Webb, W. (2020). Faculty perceptions of the use of virtual learning environments in introductory Biology courses. (Doctoral dissertation), Walden University.

Xie, X., Siau, K., \& Nah, F. F. (2020). COVID-19 pandemic - online education in the new normal and the next normal. Journal of Information Technology Case and Application Research, 22(3), 175-187. https://doi.org/10.1080/15228053.2020.1824884

\section{Copyrights}

Copyright for this article is retained by the author(s), with first publication rights granted to the journal.

This is an open-access article distributed under the terms and conditions of the Creative Commons Attribution license (http://creativecommons.org/licenses/by/4.0/). 